\title{
Oocyte developmental failure in response to elevated nonesterified fatty acid concentrations: mechanistic insights
}

\author{
V Van Hoeck, J L M R Leroy, M Arias Alvarez , D Rizos², A Gutierrez-Adan², K Schnorbusch, \\ P E J Bols, H J Leese ${ }^{3}$ and R G Sturmey ${ }^{3}$
}

Veterinary Physiology and Biochemistry, Department of Veterinary Sciences, Faculty of Biomedical, Pharmaceutical and Veterinary Sciences, Gamete Research Center, University of Antwerp, Universiteitsplein 1 - Gebouw U, B-2610 Wilrijk, Belgium, ${ }^{1}$ Departamento Producción Animal, Facultad de Veterinaria, Universidad Complutense de Madrid, Ciudad Universitaria, s/n, 28040 Madrid, Spain, ${ }^{2}$ Departamento de Reproducción Animal, Instituto Nacional de Investigacion y Tecnologia Agraria y Alimentaria, Ctra. de la Coruña Km. 5, 9, 28040 Madrid, Spain and ${ }^{3}$ Hull-York Medical School, University of Hull, Hertford Building, Cottingham Road, HU6 7RX Hull, UK

Correspondence should be addressed to V Van Hoeck; Email: veerle.vanhoeck@ua.ac.be

\begin{abstract}
Elevated plasma nonesterified fatty acid (NEFA) concentrations are associated with negative energy balance and metabolic disorders such as obesity and type II diabetes. Such increased plasma NEFA concentrations induce changes in the microenvironment of the ovarian follicle, which can compromise oocyte competence. Exposing oocytes to elevated NEFA concentrations during maturation affects the gene expression and phenotype of the subsequent embryo, notably prompting a disrupted oxidative metabolism. We hypothesized that these changes in the embryo are a consequence of modified energy metabolism in the oocyte. To investigate this, bovine cumulus oocyte complexes were matured under elevated NEFA conditions, and energy metabolism-related gene expression, mitochondrial function, and ultrastructure evaluated. It was found that expression of genes related to REDOX maintenance was modified in NEFA-exposed oocytes, cumulus cells, and resultant blastocysts. Moreover, the expression of genes related to fatty acid synthesis in embryos that developed from NEFA-exposed oocytes was upregulated. From a functional perspective, inhibition of fatty acid $\beta$-oxidation in maturing oocytes exposed to elevated NEFA concentrations restored developmental competence. There were no clear differences in mitochondrial morphology or oxygen consumption between treatments, although there was a trend for a higher mitochondrial membrane potential in zygotes derived from NEFA-exposed oocytes. These data show that the degree of mitochondrial fatty acid $\beta$-oxidation has a decisive impact on the development of NEFA-exposed oocytes. Furthermore, the gene expression data suggest that the resulting embryos adapt through altered metabolic strategies, which might explain the aberrant energy metabolism previously observed in these embryos originating from NEFA-exposed maturing oocytes.

Reproduction (2013) 145 33-44
\end{abstract}

\section{Introduction}

Elevated plasma nonesterified fatty acid (NEFA) concentrations, arising from upregulated lipolysis, have been implicated as a key factor in the association between metabolic imbalances, cellular dysfunction, and related pathologies such as insulin resistance in mammals (Shimabukuro et al. 1998, Carlsson et al. 1999, Kruszynska et al. 2002, McGarry 2002). Elevated plasma NEFA concentrations are also reflected in the bovine and human ovarian follicular microenvironments (Leroy et al. 2004, 2005, Robker et al. 2009, Jungheim et al. 2011a, 2011b, Valckx et al. 2012) and, as a result, have been associated with reduced oocyte developmental competence (Jorritsma et al. 2004, Leroy et al. 2005, Aardema et al. 2011) and compromised human and bovine granulosa cell viability (Mu et al. 2001,
Vanholder et al. 2005). In our recent study (Van Hoeck et al. 2011), it was demonstrated that embryos arising from fertilized, NEFA-exposed oocytes have a significantly lower cell number, increased apoptotic cell index, aberrant transcriptional activities, altered amino acid turnover, and compromised oxidative metabolism; all indicators for a lower embryo quality and viability. Although such embryos displayed upregulated expression of the SLC2A1 glucose transporter, they did not consume more glucose compared with control embryos, an intriguing finding, as this situation is similar to that in insulin-resistant somatic cells.

A strong metabolic role for lipid oxidation during oocyte maturation is widely acknowledged (Sturmey et al. 2006, Downs et al. 2009, Dunning et al. 2010). Aardema et al. (2011) showed that the number and size 
of lipid droplets in oocytes change following exposure to NEFA during in vitro maturation (IVM), indicating that bovine oocytes are able to incorporate and metabolize fatty acids from the external environment. However, the mechanisms through which elevated NEFA concentrations affect oocyte development and subsequent embryo physiology are unclear.

In contrast, the mechanisms underlying NEFA cytotoxicity have been extensively investigated in somatic cells where they involve modifications to cell membrane phospholipids (Calder et al. 1994), increased nitric oxide production (Shimabukuro et al. 1997), and elevated ceramide concentrations leading to apoptosis (Shimabukuro et al. 1998, Maedler et al. 2001, Lu et al. 2003). Though, Mu et al. (2001) reported that in granulosa cells, the negative effects of NEFA were unrelated to such mechanisms.

Data on somatic cells, including pancreatic $\beta$-cells (Carlsson et al. 1999, Koskin et al. 2003), adipocytes (Furukawa et al. 2004), monocytes (Zhang et al. 2006), and skeletal muscle cells (Bonnard et al. 2008), suggest that mitochondrial metabolism plays a decisive role in the etiology of fatty acid-induced metabolic disruption. Fatty acids are principally metabolized by mitochondrial $\beta$-oxidation and when their supply is plentiful, there is upregulation of mitochondrial activity (lossa et al. 2002), which results in elevated reactive oxygen species (ROS) production (Burton et al. 2003). Moreover, the mitochondrial genome possesses limited DNA repair mechanisms compared with nuclear DNA (Clayton 1991) and will potentially be more sensitive to increased ROS concentrations (Wallace 1987, Tarin 1995). In oocytes, this might be of particular relevance because mitochondria do not replicate during the early stages of preimplantation development (Cummins 2002) and each blastomere must rely on oocyte-inherited mitochondria until the blastocyst stage, when mitochondrial replication begins (Cummins 1998). Perturbations in mitochondrial function are therefore critical for oocyte development and have previously been related to embryo quality (Van Blerkom 2004).
Building on our previous work which showed that elevated NEFA concentrations during oocyte maturation affect oocyte developmental competence (Leroy et al. 2005) and the phenotype of the resulting embryos (Van Hoeck et al. 2011), we have sought to provide basic insights into the etiological mechanisms and have hypothesized that the negative effects of elevated NEFA exposure during oocyte IVM are linked to modifications in energy metabolism. To address this proposition, we have used our established bovine oocyte in vitro culture model (Van Hoeck et al. 2011) in which cumulus oocyte complexes (COCs) are exposed during maturation to elevated concentrations of stearic acid (SA), palmitic acid (PA), and oleic acid (OA) to examine whether

1. exposure to elevated NEFA concentrations alters expression profiles of target genes related to fatty acid metabolism in oocytes, cumulus cells, and the resulting 7-day-old embryos;

2. elevated NEFA exposure affects mitochondrial distribution in oocyte and ultrastructure;

3. reduced oocyte developmental potential arising from elevated NEFA exposure can be restored by modulating mitochondrial fatty acid oxidation; and

4. mitochondrial membrane polarity and oxygen consumption of zygotes are affected by exposing oocytes to elevated NEFA concentrations.

\section{Results \\ Gene expression in oocytes matured in the presence of elevated NEFA concentrations}

As shown in Fig. 1, oocytes exposed to HIGH COMBI medium displayed a significant increase in mRNA expression of lactate dehydrogenase ( $L D H A)$ and glyceraldehyde 3-phosphate dehydrogenase $(G A D P H)$, key genes involved in energy metabolism, when compared with control oocytes $(P \leq 0.02)$. Elevated $G A D P H$ expression was also observed in the HIGH SA

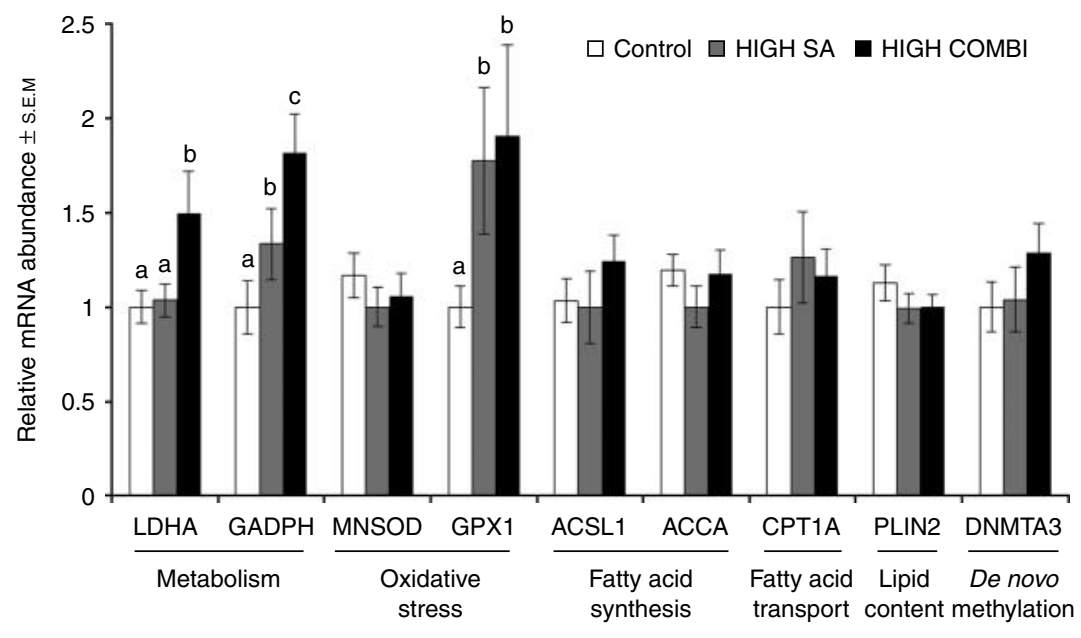

Figure 1 Comparison of relative transcript abundance in oocytes. Oocytes were matured under control (150 $\mu \mathrm{M}$ total, physiological, NEFA), HIGH SA (75 $\mu \mathrm{M} \mathrm{SA})$, and HIGH COMBI $(425 \mu \mathrm{M}$ total, elevated, NEFA) conditions ( $n=180$; three replicates). Bars with different superscripts are significantly different between treatments with $P \leq 0.02$. 


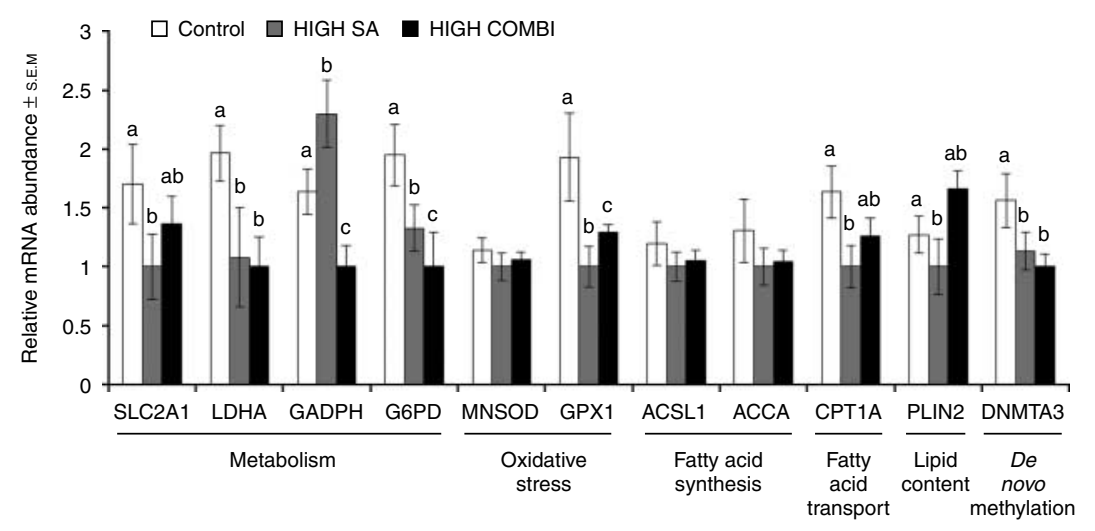

Figure 2 Comparison of relative transcript abundance in cumulus cells. Cumulus cells from cumulus oocyte complexes ( $n=180$; three replicates) matured under control ( $150 \mu \mathrm{M}$ total, physiological, NEFA), HIGH SA (75 $\mu \mathrm{M} \mathrm{SA})$, and HIGH COMBI (425 $\mu \mathrm{M}$ total, elevated, NEFA) conditions. Bars with different superscripts are significantly different between treatments with $P \leq 0.03$.

oocytes $(P \leq 0.01)$. Furthermore, the expression of glutathione peroxidase 1 (GPX1), a gene related to oxidative stress, was significantly upregulated in $\mathrm{HIGH}$ $\mathrm{SA}$ and HIGH COMBI oocytes $(P \leq 0.01)$.

\section{Gene expression in cumulus cells from COCs matured in the presence of elevated NEFA concentrations}

Figure 2 shows that expression of the facilitated glucose transporter 1 (SLC2A1), LDHA, and glucose6-phosphate dehydrogenase $(G 6 P D)$, genes related to glucose metabolism, was significantly lower in HIGH SA cumulus cells compared with cumulus cells harvested from control COCs $(P \leq 0.025)$. By contrast, the abundance of GADPH mRNA was significantly higher in $\mathrm{HIGH}$ SA cumulus cells. Cumulus cells collected from COCs matured under $\mathrm{HIGH}$ COMBI conditions displayed a significantly lower expression of $L D H A, G A D P H$, and G6PD $(P \leq 0.025)$. Expression of GPX1 and DNA cytosine-5-methyltransferase 3A (DNMT3A) was lower in cumulus cells from COCs matured in $\mathrm{HIGH}$ SA and $\mathrm{HIGH} \mathrm{COMBI}$ conditions
$(P \leq 0.03)$ compared with control COCs. Additionally, carnitine palmitoyl transferase $(C P T 1 A)$ and adipophilin 2 (PLIN2) expressions were reduced in cumulus cells collected from HIGH SA COCs $(P \leq 0.03)$.

\section{Gene expression in blastocysts originating from oocytes matured in the presence of elevated NEFA concentrations}

Four of the seven genes analyzed were differentially expressed among treatment groups (Fig. 3). First, the expression of a fatty acid synthetase (ACSL1) was dramatically upregulated in embryos originating from oocytes matured under $\mathrm{HIGH}$ COMBI concentrations compared with embryos arising from control and $\mathrm{HIGH}$ SA oocytes $(P \leq 0.05)$. Secondly, acetyl CoA carboxylase $(A C C A)$ expression was significantly higher in the group matured under $\mathrm{HIGH}$ COMBI conditions compared with the control embryos $(P \leq 0.05)$, although the group matured with $\mathrm{HIGH}$ SA concentrations did not differ from the controls or HIGH COMBI embryos. Finally, the expression of genes related to mitochondrial

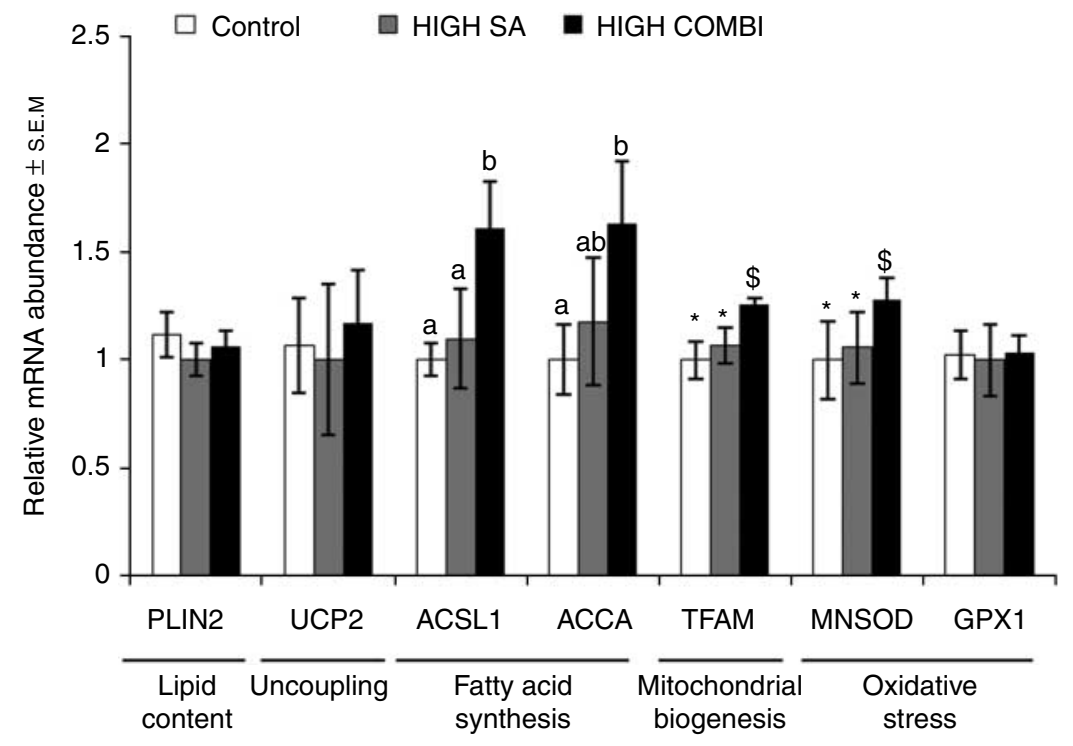

Figure 3 Expression patterns of key genes in bovine day 7 blastocysts arising from oocytes matured under control (150 $\mu \mathrm{M}$ total, physiological, NEFA), HIGH SA $(75 \mu \mathrm{M} \mathrm{SA})$, and HIGH COMBI ( $425 \mu \mathrm{M}$ total, elevated, NEFA) conditions ( $n=192$; five replicates). Bars with $\mathrm{a}$ and $\mathrm{b}$ superscripts are significantly different between treatments with $P \leq 0.05$. Bars with * and $\$$ superscripts tend to be significantly different between treatments with $P \leq 0.1$. 


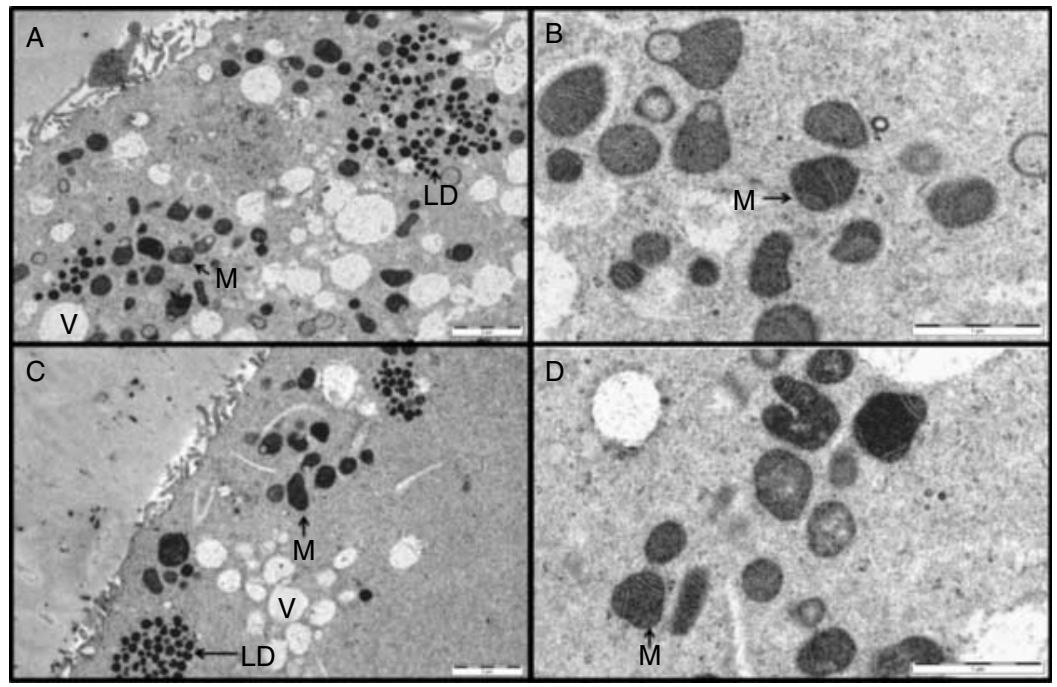

Figure 4 Electron microscopic images of mitochondria in oocytes matured under control (150 $\mu \mathrm{M}$ total, physiological, NEFA; A and B) conditions and HIGH COMBI (425 $\mu \mathrm{M}$ total, elevated, NEFA; $C$ and D) conditions at magnifications $6000 \times(\mathrm{A}$ and $\mathrm{C})$ and $25000 \times(\mathrm{B}$ and $\mathrm{D})$. Mitochondria $(\mathrm{M})$, vesicles $(\mathrm{V})$, and lipid droplets (LD) were distributed randomly in the cytoplasm. biogenesis and oxidative stress (transcription factor $\mathrm{A}$ mitochondria, TFAM, and manganese superoxide dismutase, $M N S O D$ respectively) tended to be increased in $\mathrm{HIGH}$ COMBI embryos $(P \leq 0.1)$.

\section{Mitochondrial ultrastructure and distribution in oocytes matured in the presence of elevated NEFA concentrations}

Transmission electron microscopic analysis of matured oocytes did not reveal any obvious differences in spatial distribution of mitochondria (Fig. 4, 1A and 2A). As expected (Bracket et al. 1980, Mohr \& Trounson 1981), the mitochondria of the oocyte appeared small and electron dense with few cristae, and there was little obvious difference between oocytes from the different treatments. In all the treatments, the cytoplasm was divided into organelle-rich and organelle-free zones. The organelle-rich zones displayed a slightly more peripheral localization in the ooplasm and were characterized by an apparently random distribution of mitochondria. Moreover, mitochondrial ultrastructure did not appear to change in response to HIGH NEFA exposure (Fig. 4, $1 \mathrm{~B}$ and $2 \mathrm{~B}$ ).

\section{Development of oocytes matured in the presence of elevated NEFA concentrations after inhibiting $\beta$-oxidation}

As shown in Table 1 , the presence of $\beta$-mercaptoacetate $(\beta-M A)$ had no significant effect on cleavage and blastocyst rates obtained from the fertilization of oocytes matured in control maturation medium. However, blastocyst production from oocytes matured in the presence of $\beta-\mathrm{MA}$ and HIGH COMBI NEFA was higher than when $\beta-M A$ was absent ( 26.5 vs $18.8 \% ; P=0.05$ ).

\section{Oxygen consumption in zygotes originating from oocytes matured in the presence of elevated NEFA concentrations}

No significant difference was observed in the average oxygen consumption of zygotes originating from oocytes matured under control $(1.25 \pm 0.07 \mathrm{nl} /$ embryo per $\mathrm{h})$ and HIGH COMBI (1.11 $\pm 0.11 \mathrm{nl} / \mathrm{embryo}$ per $\mathrm{h})$ conditions.

\section{Ratio of high vs low-polarized mitochondrial membranes in zygotes originating from oocytes matured in the presence of elevated NEFA concentrations}

Confocal images (Fig. 5) showed that the proportion of red pixel intensity (highly polarized membrane) out of the total red and green pixel intensity (total mitochondrial mass) was not significantly different between treatments. However, the latter percentage tended to be

Table 1 Developmental competence of NEFA-exposed oocytes in the presence and absence of $\beta$-mercaptoacetate ( $\beta-M A)$, an inhibitor of the mitochondrial $\beta$-oxidation.

\begin{tabular}{|c|c|c|c|c|}
\hline$\underline{n}(\%)$ & Control & $\begin{array}{c}\text { Control }+ \\
\beta-M A\end{array}$ & $\begin{array}{l}\text { HIGH } \\
\text { COMBI }\end{array}$ & $\begin{array}{c}\text { HIGH } \\
\text { COMBI+ } \\
\beta-M A \\
\end{array}$ \\
\hline Oocytes & 208 & 204 & 208 & 200 \\
\hline Cleaved & $172(82.7)$ & $160(78.4)$ & $162(77.9)$ & $154(77.0)$ \\
\hline $\begin{array}{l}\text { Blastocysts from } \\
\text { oocytes matured }\end{array}$ & $54(26.0)$ & $49(24.0)$ & $39(18.8)^{*}$ & $53(26.5)^{\dagger}$ \\
\hline $\begin{array}{l}\text { Blastocysts from } \\
\text { cleaved zygotes }\end{array}$ & $54(31.4)$ & $49(30.6)$ & $39(24.1)$ & $53(34.4)$ \\
\hline
\end{tabular}

Cleavage rate at day 2 p.i., number of formed blastocysts at day 7 p.i. relative to the number of matured oocytes or to the number of cleaved zygotes. Oocytes ( $n=820$; five replicates) were matured under the following conditions: i) control (150 $\mu \mathrm{M}$ total, physiological, NEFA), ii) $\mathrm{HIGH}$ COMBI $(425 \mu \mathrm{M}$ total, elevated, NEFA), iii) control $(150 \mu \mathrm{M}$ total, physiological, NEFA) $+0.1 \mathrm{mM} \beta-\mathrm{MA}$, and iv) $\mathrm{HIGH}$ COMBI $(425 \mu \mathrm{M}$ total, elevated, NEFA) + $0.1 \mathrm{mM} \beta-\mathrm{MA}$. Data marked with different superscripts are significantly different $(P<0.05)$. 

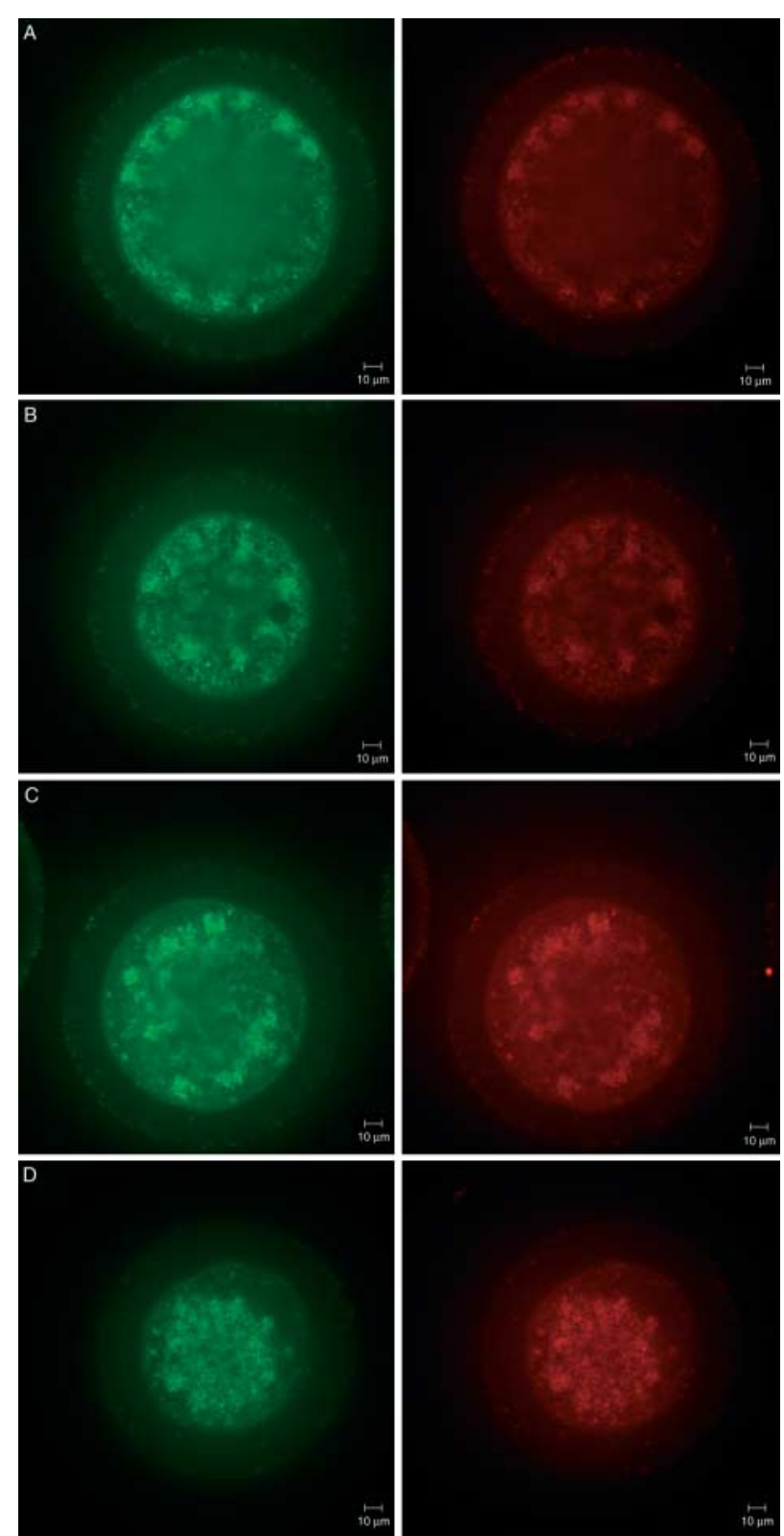

Figure 5 Confocal microscopic images $(400 \times$ magnification) of JC1-stained zygotes (day 1 p.i.) originating from oocytes matured under control (150 $\mu \mathrm{M}$ total, physiological, NEFA; A and B) and $\mathrm{HIGH}$ COMBI (425 $\mu \mathrm{M}$ total, elevated, NEFA; $C$ and $D$ ) conditions with view at midequatorial plane ( $\mathrm{A}$ and $\mathrm{C}$ ) and view at top plane (B and $\mathrm{D})$. Green fluorescence indicates low-polarized mitochondria. Red fluorescence indicates high-polarized mitochondria.

higher in $\mathrm{HIGH}$ COMBI zygotes compared with the controls for the top plane $(55.0 \% \pm 1.2$ vs $51.2 \% \pm 2.6$ respectively; $P=0.09$ ) and for the average of both the top and the midequatorial planes $(53.8 \% \pm 1.2$ vs $50.9 \%$ \pm 2.4 respectively; $P=0.09$ ). No difference in mitochondrial membrane polarity ratios could be detected between treatments for the midequatorial plane $(52.9 \% \pm 1.2$ vs $50.7 \% \pm 2.5$ respectively; $P=0.17)$.

\section{Discussion}

Elevated NEFA concentrations represent a common feature of a distorted maternal metabolism, typically present in obese and type II diabetes patients (Reaven et al. 1988, Mooradian et al. 2008). Epidemiological studies suggest that such metabolic disorders are associated with decreased fertility (Pasquali et al. 2003, Metwally et al. 2007), and there is growing evidence that elevated NEFA concentrations play a key role in this process as they may alter the biochemical composition of the follicular microenvironment (Leroy et al. 2005, Robker et al. 2009, Jungheim et al. 2011a, 2011b, Valckx et al. 2012). Such adverse follicular conditions during oocyte maturation can interfere with the oocyte's developmental capacity (Jorritsma et al. 2004, Leroy et al. 2005, 2012, Aardema et al. 2011). Furthermore, embryos originating from oocytes exposed to elevated NEFA concentrations exhibit an altered oxidative metabolism, compromised glucose metabolism, and an altered gene expression pattern as they develop up to day 7 (Van Hoeck etal. 2011).

In this study, we investigated the etiological mechanisms by which these events occur. We have used cows in negative energy balance (NEB) as a model system to investigate the lipotoxic effects of elevated NEFA on the oocyte. Although there are obvious differences between ruminant NEB and human obese of type II diabetes conditions, both ultimately lead to upregulated lipolysis and to elevated serum NEFA concentrations. The types and the concentrations of the NEFA used in the present model are based on the studies on follicular fluid in situ under conditions of upregulated lipolysis and thus are physiologically relevant (Leroy et al. 2005). We know from human follicular fluid analyses that our bovine observations accurately replicate the situation in the human. Furthermore, human serum NEFA concentrations under obese conditions (Hall \& Saunders 1979, Reaven et al. 1988, Stolba et al. 1993) are very similar to the bovine serum NEFA concentrations during NEB (Leroy et al. 2005). We therefore hypothesized that the compromised oocyte developmental competence, which results from NEFA exposure during the final stages of maturation, is caused by modifications in oocyte energy metabolism, a concept based on the fundamental research in myocardial cells exposed to elevated NEFA concentrations, in which high fatty acid $\beta$-oxidation rates contribute to the development of myocardiopathies (for an overview: Lopaschuk et al. (2010)). Interestingly, Igosheva et al. (2010) also reported that excessive nutrient exposure before and during conception in obese mice might be associated with a compromised oocyte and embryo mitochondrial metabolism.

At the molecular level, oocytes matured in medium with elevated concentrations of palmitic, stearic, and OA showed a significant increase in mRNA encoding $G A D P H$ and $L D H A$. GADPH catalyzes the sixth step of 
glycolysis, converting $\mathrm{NAD}^{+}$to $\mathrm{NADH}$ and thus generating reducing power. $\angle D H A$ is also recognized as a strong cytosolic reductant (Lane \& Gardner 2000) as it preferentially converts lactate into pyruvate (Dumollard et al. 2007, Wilding et al. 2009), with the conversion of $\mathrm{NAD}^{+}$to $\mathrm{NADH}$. It is also noteworthy that the products of these two genes regulate transcription by virtue of their ability to interact with the transcriptional cofactor Oct1 in a REDOX-dependent manner (Zheng et al. 2003). Furthermore, the HIGH $\mathrm{COMBI}$ oocytes showed significant upregulation of GPX1 expression, a ROS-related gene, which supports our proposition that the REDOX status of the oocyte is affected by exposure to high NEFA. GPX1 is of fundamental importance since it acts in the detoxification of hydrogen peroxide. Interestingly, increased expression of GADPH will spare $\mathrm{NAD}(\mathrm{P}) \mathrm{H}$, which is essential for the recycling of glutathione. In other words, the differential expression of these specific genes in response to NEFA exposure may provide a mechanism for the imbalance in intracellular REDOX potential, as reported in the previous studies in leucocytes (Kakinuma \& Minakami 1978, Listenberger et al. 2001), a state characterized by an imbalance between pro-oxidant molecules including ROS and antioxidant defenses. A moderate increase in ROS levels can stimulate cell growth and proliferation and is physiologically important. Conversely, excessive ROS will cause cellular injury (e.g. damage to DNA, lipid membranes, and proteins). Mitochondria are major sites for ROS production and excessive ROS can affect their function in oocytes and embryos (for review: Agarwal et al. (2012)).

In contrast to the observations in the oocyte, cumulus cells from HIGH NEFA-exposed COCs exhibited downregulated expression of genes encoding enzymes involved in REDOX regulation: GADPH, GPX1, G6PD, and $L D H A$. Furthermore, expression of the DNMT3A gene was significantly downregulated in HIGH COMBI and HIGH SA cumulus cells, pointing to the possibility of altered methylation status. Cumulus cells are vital for the oocyte to complete successful maturation and sustain further development (Tanghe et al. 2002). Moreover, cumulus cells likely play a role in regulating REDOX homeostasis by providing glutathione to the oocyte (Geshi et al. 2000). If the cumulus cells do not succeed in safeguarding this system and fail to protect the oocytes, there could be a compensating mechanism in oocytes to upregulate their own defense against ROS. Thus, impaired viability and anti-ROS defense of the cells surrounding the oocyte most likely reflects jeopardized oocyte capacity to defend against ROS, consistent with the significant upregulated GPX1 and $L D H A$ expression in the oocyte.

As a result of our own work (Van Hoeck et al. 2011) and that of others (Rizos et al. 2002, Lonergan et al. 2003, Sirard et al. 2006), it can be concluded that the nutritional environment during maturation can affect the resulting embryo. We therefore examined whether blastocysts originating from NEFA-exposed oocytes displayed differences in transcript abundance of key genes. The HIGH COMBI blastocysts tended to display upregulated expression of MNSOD, an enzyme that plays a protectant role against oxidative stress (Harvey et al. 1995), which might be the result of a compensatory mechanism in response to a shifted REDOX potential at earlier stages of development and in turn affect the activity of REDOX-sensitive transcription factors, a suggestion supported by our previous demonstration of SLC2A1 mRNA upregulation in HIGH COMBI embryos (Van Hoeck et al. 2011). Moreover, the HIGH COMBI embryos showed higher expression of TFAM, which is essential in stabilizing mitochondrial DNA and for which overexpression is reported to be related to oxidative stress (Suarez et al. 2008). Interestingly, a significant increase was also observed in the mRNA encoding enzymes involved in the fatty acid synthesis pathways; namely ACSL 1 and ACCA in HIGH COMBI blastocysts. ACSL1 is involved in the activation of longchain fatty acid for $\beta$-oxidation; however, when malonyl Co $\mathrm{A}$, the product of ACCA, is also abundant, there is a shift toward synthesis of triglycerides. The parallel increase in the mRNA abundance of ACSL1 and ACCA suggests increased lipogenesis in such embryos as ACSL 1 has been closely linked to triglyceride synthesis, and overexpression suggests a mechanism for sequestering fatty acids as triacylglycerols in lipid droplets (Li et al. 2010). The ability to store NEFA in lipid droplets might have a protective function in channeling fatty acids away from other lipotoxic pathways that may have been triggered at oocyte level (Cnop et al. 2001, Li et al. 2010). However, previous studies in somatic cell lines have demonstrated that excessive accumulation of lipids in peripheral tissues is closely associated with the pathological state of insulin resistance in type II diabetes (Zhang \& Zhang 2012). Therefore, the question arises whether such adaptations toward lipid storage provide protective/compensatory mechanisms or rather activate other toxicity-related pathways. Both options may have an important impact during further embryo development, implantation, and fetal development, problems that might not become apparent until postimplantation, fetal, or even neonatal development.

As the organization, positioning, and morphology of mitochondria within the oocyte are indicative of the energy requirements of key events during oocyte maturation (Sun et al. 2001), we evaluated mitochondrial distribution in oocytes matured in the presence and absence of elevated NEFA. Although mitochondrial organization differs between morphologically good and poor oocytes and may be associated with different developmental capacity after IVF (Stojkovic et al. 2001), transmission electron microscopic analyses did not reveal obvious differences in 
oocyte mitochondrial distribution or morphology between HIGH COMBI oocytes and controls.

We next sought to investigate the functional effects of exposure to high NEFA on mitochondrial activity, by testing the effect of $\beta$-oxidation inhibition during oocyte maturation. A strong metabolic role for lipid oxidation during oocyte maturation has been substantiated previously in mouse (Downs et al. 2009, Dunning et al. 2010) and bovine oocytes (Sturmey et al. 2006). Using $\beta-M A$, an enzyme that inhibits the $\beta$-oxidation, we found that the developmental potential of $\mathrm{HIGH}$ COMBI oocytes could be rescued if $\beta$-oxidation was inhibited during oocyte maturation $(P=0.05)$. This suggests that mitochondrial fatty acid $\beta$-oxidation is involved in developmental failure in bovine oocytes exposed to elevated NEFA concentrations. By contrast, control oocytes exposed to basal NEFA concentrations did not display significant differences in postfertilization development after inhibition of $\beta$-oxidation, which is in line with the findings from Sturmey et al. (2006). We have previously shown that the oxygen consumption of embryos originating from NEFA-exposed oocytes is significantly reduced (Van Hoeck et al. 2011) and therefore wished to discover whether such a reduction in oxygen consumption was already evident directly after maturation. As it was not possible to measure the respiration of the oocyte alone, due to the presence of surrounding cumulus cells (Wilding et al. 2009), oxygen consumption was determined in zygotes originating from HIGH NEFA-exposed oocytes. We also measured the ratio of high vs low-polarized mitochondrial membranes in these zygotes to provide a global picture of mitochondrial activity as this feature has been positively correlated with the level of respiration (Miwa \& Brand 2003, Van Blerkom et al. 2006). The oxygen consumption of zygotes was not significantly different between treatments. Likewise, confocal analyses did not reveal major differences in the activity of mitochondria in zygotes arising from the different treatments, although there was a tendency for an increased ratio of high vs low-polarized mitochondrial membranes in HIGH NEFA zygotes. One possible explanation for this observation might relate to the metabolic plasticity of the early embryo. Measuring oxygen consumption and the ratio of high vs low-polarized mitochondrial membranes provides information on overall oxidative process in terms of ATP synthesis from oxidative phosphorylation. However, the identity of the major substrate oxidized to generate the ATP cannot be determined from such experiments. The observation that inhibition of $\beta$-oxidation during maturation restores developmental capacity in NEFA-exposed oocytes does, however, strongly suggest that the pathways adopted by the early embryo to generate substrates for oxidation are crucial in determining ongoing viability and might be influenced by the conditions under which the oocyte matures. If the oocyte is unable to oxidize fatty acids for the generation of ATP, one can speculate that it alters its metabolism to oxidize alternative exogenous substrates such as pyruvate, lactate, and glucose (Sutton-McDowall et al. 2010).

The follicular microenvironment before conception is crucial for maturing oocytes (for an overview: Leroy et al. (2012)). As such, using a bovine in vitro production model, we were able to demonstrate that elevated NEFA concentrations during the final phase of oocyte maturation compromise further development and even alter the gene expression pattern of the resultant embryo, which substantiates our previous work (Leroy et al. 2005, Van Hoeck et al. 2011). However, Britt (1994) hypothesized that the developmental competence of oocytes, in high-yielding dairy cows, is determined by their biochemical environment during a long period (up to 80 days) of follicular growth before ovulation. So far, studies determining the effects of a long-term NEFA exposure during folliculogenesis and oogenesis have not been performed, though might be crucial in determining the final fate of oocytes dwelling in NEFAexposed follicles.

\section{Conclusions}

Our data indicate that the follicular conditions under which the oocyte completes final maturation have a significant effect on the subsequent embryo in terms of gene and molecular/cellular phenotypic expression, particularly with regard to metabolically critical REDOX- and FAS-related gene function, as well as influencing the metabolic strategy of the early embryo. We can speculate that such profound alterations apparent at the oocyte stage may persist in fetal development and in the offspring.

\section{Materials and Methods}

\section{Preparation of NEFA treatments}

All chemicals were purchased from Sigma unless otherwise stated. SA, PA, and OA were dissolved in a stock solution of pure ethanol at concentrations of 25, 150, and $200 \mathrm{mM}$ respectively. These ethanol stock solutions were vortex mixed for $4 \mathrm{~min}$ and diluted in working solutions to obtain the desired final concentration in maturation medium. The serumfree maturation medium consisted of TCM199 supplemented with $0.75 \%$ BSA free of fatty acids, $0.4 \mathrm{mM}$ glutamine, $0.2 \mathrm{mM}$ sodium pyruvate, $0.1 \mathrm{mM}$ cysteamine, $50 \mu \mathrm{g} / \mathrm{ml}$ gentamicin, and murine epidermal growth factor $(20 \mathrm{ng} / \mathrm{ml})$. All solutions were shaken for $45 \mathrm{~min}$ and filter sterilized under aseptic conditions.

\section{In vitro embryo production}

Bovine ovaries were collected at local abattoirs as soon as possible after killing and transported immediately to the laboratory. They were washed three times in warm saline 
solution $\left(38{ }^{\circ} \mathrm{C}\right)$ supplemented with $0.5 \%$ kanamycin sulfate. Follicles with a diameter of $2-6 \mathrm{~mm}$ were aspirated. Unexpanded COCs surrounded by five or more cumulus cell layers (quality grade I) were matured in vitro as described by Leroy et al. (2010). The COCs were washed in $500 \mu \mathrm{l}$ maturation medium and matured in groups of 50-60 COCs in $500 \mu \mathrm{l}$ maturation medium in four-well plates (Nunc, Langenselbold, Germany) for 22-24 h in humidified air with $5 \% \mathrm{CO}_{2}$ at $38.5^{\circ} \mathrm{C}$. After IVM, all COCs were coincubated in groups of 100-120 with spermatozoa at a final concentration of $10^{6} \mathrm{sperm}$ cells $/ \mathrm{ml}$ for $20 \mathrm{~h}$ at $38.5^{\circ} \mathrm{C}$ in $500 \mu$ fertilization medium in a humidified $5 \% \mathrm{CO}_{2}$ incubator. For all experiments, frozen semen from a bull of proven IVF (Van Hoeck et al. 2011) was thawed and live spermatozoa were selected by centrifugation on a discontinuous Percoll gradient (90 and 45\%, Amersham Biosciences). The final sperm-egg ratio was adjusted to 5000:1. Fertilization medium consisted of $114 \mathrm{mM}$ $\mathrm{NaCl}, 3.1 \mathrm{mM} \mathrm{KCl}, 0.3 \mathrm{mM} \mathrm{Na}{ }_{2} \mathrm{HPO}_{4}, 2.1 \mathrm{mM} \mathrm{CaCl}{ }_{2} \cdot 2 \mathrm{H}_{2} \mathrm{O}$, $0.4 \mathrm{mM} \mathrm{MgCl} \cdot 6 \mathrm{H}_{2} \mathrm{O}, 25 \mathrm{mM}$ bicarbonate, $1 \mathrm{mM}$ pyruvate, $36 \mathrm{mM}$ lactate, $2 \mu \mathrm{l} / \mathrm{ml}$ phenol red, $6 \mathrm{mg} / \mathrm{ml} \mathrm{BSA}, 50 \mu \mathrm{g} / \mathrm{ml}$ gentamycin, and $10 \mu \mathrm{l} / \mathrm{ml}$ heparin. After coincubation with spermatozoa, the presumptive zygotes were vortexed for $4 \mathrm{~min}$ to remove excess sperm and cumulus cells. After three wash steps in HEPES-TALP and modified SOF medium, presumptive zygotes were cultured in groups of $25 \pm 4$ in $50 \mu \mathrm{l}$ modified SOF medium with mineral oil overlay (modular incubator: $38.5{ }^{\circ} \mathrm{C}, 5 \% \mathrm{CO}_{2}, 5 \% \mathrm{O}_{2}$, and $90 \% \mathrm{~N}_{2}$ ) until day 7 p.i. The SOF medium comprised $108 \mathrm{mM} \mathrm{NaCl}, 7.2 \mathrm{mM} \mathrm{KCl}$, $1.2 \mathrm{mM} \mathrm{KH} \mathrm{PO}_{4}, 0.8 \mathrm{mM} \mathrm{MgSO} \cdot \cdot 7 \mathrm{H}_{2} \mathrm{O}, 0.6 \mathrm{mM}$ sodium lactate, $25 \mathrm{mM} \mathrm{NaHCO}, 0.0266 \mathrm{mM}$ phenol red, $0.73 \mathrm{mM}$ sodium pyruvate, $1.78 \mathrm{mM} \mathrm{CaCl} 2 \cdot 2 \mathrm{H}_{2} \mathrm{O}, 0.34 \mathrm{mM}$ trisodium citrate, $2.755 \mathrm{mM}$ myoinositol, 3\% v/v BME 50x, 1\% v/v MEM $100 x, 0.4 \mathrm{mM}$ glutamine, 5\% fetal bovine serum, and $50 \mu \mathrm{g} / \mathrm{ml}$ gentamycin.

\section{Composition of the oocyte maturation treatments}

The types and concentrations of free fatty acids used in this study are based on bovine in vivo studies in serum and in follicular fluid (Leroy et al. 2005) and are physiologically appropriate, as circulating NEFA concentrations in women suffering lipolysis-linked metabolic disorders, including obesity (Reaven et al. 1988, Stolba et al. 1993), are very similar to NEFA concentrations detected in bovine during an episode of upregulated lipolysis (Leroy et al. 2005).

Standard serum-free maturation systems are devoid of fatty acids, although the physiological environment, in which the oocyte matures in vivo, contains physiological, basal concentrations of NEFA (Leroy et al. 2005). In order to improve the relevance of our in vitro model, we therefore used a maturation medium supplemented with basal NEFA concentrations as control medium. We showed that inclusion of physiological concentrations of the key NEFA in maturation media formulations (three replicates; 595 oocytes) does not affect developmental competence compared with standard serum-free maturation media $(P>0.1$, details in Van Hoeck et al. (2011)). Moreover, in previous studies, we identified SA as the most toxic NEFA for oocyte developmental competence
(Leroy et al. 2005, Van Hoeck et al. 2011). We therefore focused on the following NEFA treatments in this study:

1. control $=$ physiological NEFA concentrations $(150 \mu \mathrm{M}$ total NEFA comprising $25 \mu \mathrm{M} \mathrm{SA}, 50 \mu \mathrm{M}$ PA, and $75 \mu \mathrm{M} \mathrm{OA})$

2. $\mathrm{HIGH} \mathrm{SA}=$ elevated $\mathrm{SA}$ concentrations $(75 \mu \mathrm{M} \mathrm{SA})$

3. $\mathrm{HIGH} C \mathrm{COMBI}=$ combination of elevated NEFA concentrations (425 $\mu \mathrm{M}$ total NEFA, comprising $75 \mu \mathrm{M} \mathrm{SA}, 150 \mu \mathrm{M}$ $\mathrm{PA}$, and $200 \mu \mathrm{M} \mathrm{OA})$.

\section{RNA extraction, $R T$, and quantification of $m R N A$ transcript abundance}

For gene expression analysis, cumulus cells were separated from the mature oocytes by repeated aspiration with a smallbore glass pipette. Poly(A) RNA of cumulus cells, oocytes, and day 7 blastocysts was extracted using a Dynabead mRNA Direct Extraction KIT (Dynal Biotech, Madrid, Spain) according to the manufacturer's instructions, with minor modifications. Immediately after extraction, the RT reaction was carried out following the manufacturer's instructions (Bioline, London, UK), using poly $(\mathrm{T})$ primer, random primers, and the MMLV reverse transcriptase enzyme, in a total volume of $40 \mu \mathrm{l}$, in order to prime the RT reaction and to synthesize cDNA. Tubes were heated to $70{ }^{\circ} \mathrm{C}$ for 5 min to denature the secondary RNA structure and the RT reaction was completed with the addition of 100 units of reverse transcriptase. The mixture was incubated at $42{ }^{\circ} \mathrm{C}$ for $60 \mathrm{~min}$ to allow the RT of RNA, followed by $70^{\circ} \mathrm{C}$ for $10 \mathrm{~min}$ to denature the RT enzyme. The quantification of all mRNA transcripts was carried out by realtime quantitative RT-PCR (qPCR). For qPCR, four groups of CDNA per experimental group were used with two replicates for all genes of interest. Experiments were conducted to compare relative levels of each transcript and histone $H 2 A F Z$ in every sample. The PCR was performed by adding a $2 \mu \mathrm{l}$ aliquot of each sample to the PCR mix, containing the specific primers, to amplify the genes of interest. Primer sequences and the approximate sizes of the amplified fragments of all transcripts are shown in Table 2. For quantification, qPCR was performed as described previously (Bermejo-Alvarez et al. 2010). PCR conditions were optimized to achieve efficiencies close to 1 and the comparative cycle threshold $(C T)$ method used to quantify expression levels as described by Schmittgen \& Livak (2008). Quantification was normalized to the endogenous control H2AFZ. The genes chosen have been associated with aspects of embryo energy metabolism: $L D H A$, $G A D P H$, facilitated glucose transporter 1 (SLC2A1), and G6PD; oxidative stress: MNSOD and GPX1; de novo methylation: DNMT3A; mitochondrial biogenesis: TFAM; and fatty acid metabolism: CPT1A, adipophilin 2 (PLIN2), ACCA, mitochondrial uncoupling protein 2 (UCP2), and transcription factor A, mitochondrial (ACSL1), all of which have been reported to play a key role in NEFA toxicity pathways in several cell types. A total of 180 COCs were used to analyze gene expression in cumulus cells and oocytes in three independent repeats and 192 blastocysts were used for gene expression analysis in five independent repeats (samples equally distributed along treatments). 
Table 2 Details of primers used for qRT-PCR.

\begin{tabular}{|c|c|c|c|}
\hline Gene & Primer sequence $\left(5^{\prime}-3^{\prime}\right)$ & Fragment size (bp) & GenBank accession no. \\
\hline$H 2 A F Z$ & AGGACGACTAGCCATGGACGTGTG & 212 & NM_016750 \\
\hline PLIN2 & $\begin{array}{l}\text { ACAACACACСССТCAACTGG } \\
\text { CTGCCTGCCTACTTCAGACC }\end{array}$ & 211 & ВТ029909.1 \\
\hline$M N S O D$ & $\begin{array}{l}\text { GCTTACAGATTGCTGCTTGT } \\
\text { AAGGTAATAAGCATGCTCCC }\end{array}$ & 101 & S67818.1 \\
\hline CPT1A & $\begin{array}{l}\text { CTGCCCGCCTGGGAAATGCTGT } \\
\text { CAGTCTCTCCTCCCCGGGCTGG }\end{array}$ & 328 & NM_001034349.2 \\
\hline ACSL1 & $\begin{array}{l}\text { TGACTGTTGCTGGAGACTGG } \\
\text { TGTGCTTCTTCCTGTCGATG }\end{array}$ & 250 & NM_001076085.1 \\
\hline$L D H A$ & $\begin{array}{l}\text { TTCTTAAGGAAGAACATGTC } \\
\text { TTCACGTTACGCTGGACCAA }\end{array}$ & 310 & NM_174099.2 \\
\hline$G P X 1$ & $\begin{array}{l}\text { GCAACCAGTTTTGGGCATCA } \\
\text { CTCGCACTTTTCGAAGAGCATA }\end{array}$ & 116 & NM_174076.3 \\
\hline$A C C A$ & $\begin{array}{l}\text { AAGCAATGGATGAACCTTCTTC } \\
\text { GATGCCCAAGTCAGAGAGC }\end{array}$ & 196 & FN185963.1 \\
\hline$G A D P H$ & $\begin{array}{l}\text { ACCCAGAAGACTGTGGATGG } \\
\text { AYGCCTGCTTCACСАССТTC }\end{array}$ & 247 & BC102589 \\
\hline$S L C 2 A 1$ & $\begin{array}{l}\text { CTGATCCTGGGTCGCTTCAT } \\
\text { ACGTACATGGGCACAAAACCA }\end{array}$ & 68 & NM_174602.2 \\
\hline G6PD & $\begin{array}{l}\text { CGCTGGGACGGGGTGCCCTTCATC } \\
\text { CGCCAGGCCTCCCGCAGTTCATCA }\end{array}$ & 347 & XM_583628.4 \\
\hline DNMT3A & $\begin{array}{l}\text { CTGGTGCTGAAGGACTTGGGC } \\
\text { CAGAAGAAGGGGCGGTCATC }\end{array}$ & 318 & AY271299 \\
\hline
\end{tabular}

\section{Mitochondrial morphological evaluation, ultrastructure, and distribution}

Immediately following maturation, COCs were fixed in $4 \%$ formaldehyde for 1-3 $\mathrm{h}$ and prepared for transmission electron microscopy according to Abe et al. (1999). COCs were washed in PBS and postfixed for $1 \mathrm{~h}$ with $1 \%$ osmium tetroxide in PBS at $0-4{ }^{\circ} \mathrm{C}$. Subsequently, the COCs were individually embedded in $1 \%$ agar before the epoxy resin embedding process. All samples were dehydrated in ascending concentrations of ethanol solutions (50-100\%), substituted in propylene oxide, and embedded in epoxy resin. Ultra-thin sections were prepared using an ultramicrotome. These sections were stained with uranyl acetate and lead citrate and examined with a transmission electron microscope operated at $60 \mathrm{kV}$. In total, 15 COCs, equally distributed along treatments, were visualized.

\section{Evaluation of the effect of $\beta$-oxidation inhibition}

$\beta$-Oxidation was inhibited by incubation with $\beta-M A$, a competitive inhibitor of 3-hydroxyl CoA dehydrogenase, a component of the $\beta$-oxidation pathway (Sturmey et al. 2006). During a serum-free maturation period of $24 \mathrm{~h}$, bovine COCs were exposed to the following treatments: i) control, ii) $\mathrm{HIGH} C O M B I$, iii) control $+0.1 \mathrm{mM} \beta-\mathrm{MA}$, and iv) $\mathrm{HIGH}$ $\mathrm{COMBI}+0.1 \mathrm{mM} \beta-\mathrm{MA}$. Following IVF, zygotes were cultured in SOF $(+5 \%$ of FCS) medium as described earlier. Cleavage ( 2 days p.i.) and blastocyst rates (7 days p.i.) were defined as the number of cleaved zygotes or blastocysts formed per oocyte matured respectively. The number of blastocysts from cleaved zygotes was also recorded. A total of 820 COCs, equally allocated over treatments, was used in five independent replicates.

\section{Oxygen consumption analysis}

As the maturing oocyte is surrounded by cumulus cells, it is not relevant to measure respiration of the oocyte alone (Wilding et al. 2009). Oxygen consumption and mitochondrial membrane potential were therefore measured in zygotes after they had been denuded of cumulus oophorus. Individual zygotes day 1 p.i. were loaded into a PCR Glass micropipette (Drummond, Broomal, PA, USA) and allowed to respire for $30 \mathrm{~min}$ to form an oxygen gradient, which was measured in real time using a nanorespirometer (Unisense, Aarhus, Denmark) and converted to oxygen consumption rate using SensorTrace Pro (Unisense) according to the previous studies (Lopes et al. 2005, Van Hoeck et al. 2011). In total, 54 zygotes, equally distributed along treatments, were analyzed on three independent occasions.

\section{Analysis of the ratio of high vs low-polarized mitochondrial membranes}

Bovine zygotes were stained with 5,5'6,6'-tetrachloro-1,1,3,3'tetraethylbenzimidazoly-carbocyanine iodide (JC1) following the method of Van Blerkom et al. (2002). Briefly, zygotes at day 1 p.i. were washed three times in PBS and incubated in SOF culture medium containing $2 \mu \mathrm{g} / \mathrm{ml} \mathrm{JC}-1$ in a modular incubator $\left(38.5{ }^{\circ} \mathrm{C}, 5 \% \mathrm{CO}_{2}, 5 \% \mathrm{O}_{2}\right.$, and $\left.90 \% \mathrm{~N}_{2}\right)$ for $25 \mathrm{~min}$. Subsequently, the zygotes were washed three times and transferred into imaging dishes, protected from light, and immediately evaluated on a PerkinElmer Ultraview Vox confocal microscope (Waltham, MA, USA) in the FITC (bandpass 500-550 nm), rhodamine isothiocyanate (bandpass 580-650 nm) channels with narrow band filter sets as shown in Fig. 5. Images were acquired using Volocity 6.0.1 software and data on pixel intensity in each channel were determined with ImageJ, a Java image-processing program, with sample origin 
blinded to the scorer. In each zygote, the ratio of high vs lowpolarized mitochondrial membranes was estimated as the percentage of the red pixel intensity (highly polarized membrane) out of the total red and green pixel intensity (total mitochondrial mass). A total of 62 zygotes, equally distributed along treatments, were analyzed, at both the top and the midequatorial plane (Fig. 5), on three independent occasions.

\section{Statistical analyses}

Data are expressed as mean \pm s.E.M. except for the $\beta-M A$ experiment. Relative transcript abundance was analyzed using the SigmaStat (Jandel Scientific) software package using oneway ANOVA with multiple pairwise comparisons using the Student-Newman-Kleus method post hoc. Other statistical procedures were carried out with PASW Data Collection 5.6 (for Windows, Chicago, IL, USA). For the $\beta$-MA experiment, cleavage and blastocyst rates were compared between the three treatments using a binary logistic regression model taking replicate, treatment, and the interaction term into account. Where no significant interaction was present, the term was omitted from the final model. For oxygen consumption and ratio of high vs low-polarized mitochondrial membranes, a mixed model ANOVA, taking treatment as fixed factor and replicate as random factor, was used to compare differences between the three groups. Replicate, treatment, and the interaction term were taken into account. If no significant interaction was present, the term was omitted from the final model. Data transformations were not required for inequality of variance between groups nor for achieving normality for any data.

\section{Declaration of interest}

The authors declare that there is no conflict of interest that could be perceived as prejudicing the impartiality of the research reported.

\section{Funding}

This work was supported by the Flemish Research Fund (FWO grant 1106910N: V Van Hoeck), GEMINI COST ACTION FA0702 (short mission scientific stay in RGS's lab), the Spanish Ministry of Science and Innovation (A Gutierrez-Adan by Grant AGL2009-11358; D Rizos by Grant AGL2009-11810), and the Special Research Fund (BOF-UA: J L M R Leroy). $M$ Arias Alvarez is postdoctoral researcher funded by the Spanish Ministry for Science and Education. The PerkinElmer Ultraview Vox was purchased with support of the Hercules Foundation (Hercules Type 1: AUHA-09-001).

\section{Acknowledgements}

The authors acknowledge Els Merckx and Silke Andries, of the University of Antwerp Gamete Research Center, for their outstanding technical assistance with IVP and also Meg Stark, of the University of York Technology Facility, for excellent guidance in electron microscopy and the Ministry for Education and Science of Spain.

\section{References}

Aardema H, Vos PLAM, Lolicato F, Roelen BAJ, Knijn HM, Vaandrager AB, Helms JB \& Gadella BM 2011 Oleic acid prevents detrimental effects of saturated fatty acids on bovine oocyte developmental competence. Biology of Reproduction 85 62-69. (doi:10.1095/biolreprod.110. 088815)

Abe H, Yamashita S, Takehiro I, Takeshi S \& Hoshi H 1999 Ultrastructure of bovine embryos developed from in vitro-matured and -fertilized oocytes: comparative morphological evaluation of embryos cultured either in serum-free medium or in serum-supplemented medium. Molecular Reproduction and Development 53 325-335. (doi:10.1002/(SICl)10982795(199907)53:3<325::AID-MRD8 > 3.0.CO;2-T)

Agarwal A, Aponte-Mellado A, Premkumar BJ, Shaman A \& Gupta S 2012 The effects of oxidative stress on female reproduction: a review. Reproductive Biology and Endocrinology 10 49. (doi:10.1186/14777827-10-49)

Bermejo-Alvarez P, Rizos D, Rath D, Lonergan P \& Gutierrez-Adan A 2010 Sex determines the expression level of one third of the actively expressed genes in bovine blastocysts. PNAS 107 3394-3399. (doi:10.1073/pnas. 0913843107)

Bonnard C, Durand A, Peyrol S, Chanseaume E, Chauvin MA, Morio B, Vidal H \& Rieusset J 2008 Mitochondrial dysfunction results from oxidative stress in the skeletal muscle of diet-induced insulin-resistant mice. Journal of Clinical Investigation 118 789-800. (doi:10.1172/ JCl32601)

Bracket BG, Oh YK, Evans JF \& Donawick WJ 1980 Fertilization and early development of cow ova. Biology of Reproduction 23 189-205. (doi:10. 1095/biolreprod23.1.189)

Britt JH 1994 Follicular development and fertility: potential impacts of negative energy balance. Proceedings of the National Reproduction Symposium 103-112.

Burton GJ, Hempstock J \& Jauniaux E 2003 Oxygen, early embryonic metabolism and free radical-mediated embryopathies. Reproductive Biomedicine Online 6 84-96. (doi:10.1016/S1472-6483(10)62060-3)

Calder PC, Yaqoob P \& Harvey DJ 1994 Incorporation of fatty acids by concavalin A-stimulated lymphocytes and the effect on fatty acid composition and membrane fluidity. Biochemical Journal $\mathbf{3 0 0}$ 509-518.

Carlsson C, Hakan B \& Welsh N 1999 Sodium palmitate induces partial mitochondrial uncoupling and reactive oxygen species in rat pancreatic islets in vitro. Endocrinology 140 3422-3428. (doi:10.1210/ en.140.8.3422)

Clayton DA 1991 Replication and transcription of vertebrate mitochondrial DNA. Annual Review of Cell Biology 7 453-478. (doi:10.1146/annurev. cb.07.110191.002321)

Cnop M, Hannaert JC, Hoorens A, Eizirik DL \& Pipeleers DG 2001 Inverse relationship between cytotoxicity of free fatty acids in pancreatic islet cells and cellular triglyceride accumulation. Diabetes 50 1771-1777. (doi:10.2337/diabetes.50.8.1771)

Cummins J 1998 Mitochondrial DNA in mammalian reproduction. Reviews of Reproduction 3 172-182. (doi:10.1530/ror.0.0030172)

Cummins J 2002 The role of maternal mitochondria during oogenesis, fertilisation and embryogenesis. Reproductive Biomedicine Online 4 176-182. (doi:10.1016/S1472-6483(10)61937-2)

Downs SM, Mosey JL \& Klinger J 2009 Fatty acid oxidation and meiotic resumption in mouse oocytes. Molecular Reproduction and Development 76 844-853. (doi:10.1002/mrd.21047)

Dumollard R, Ward Z, Carroll J \& Duchen MR 2007 Regulation of redox metabolism in the mouse oocyte and embryo. Development 134 455-465. (doi:10.1242/dev.02744)

Dunning KR, Cashman K, Russell DL, Thompson JG, Norman RJ \& Robker RL 2010 -Oxidation is essential for mouse oocyte developmental competence and early embryo development. Biology of Reproduction 83 909-918. (doi:10.1095/biolreprod.110.084145)

Furukawa S, Fujita T, Shimabukuro M, Iwaki M, Yamada Y, Nakajima $Y$, Makishima O, Matsuda M \& Shimomura M 2004 Increased oxidative stress in obesity and its impact on metabolic syndrome. Journal of Clinical Investigation 114 1752-1761. (doi:10.1172/JCl200421625)

Geshi M, Takenouchi N, Yamauchi N \& Nagai T 2000 Effects of sodium pyruvate in nonserum maturation medium on maturation, fertilization 
and subsequent development of bovine oocytes with or without cumulus cells. Biology of Reproduction 63 1130-1734. (doi:10.1095/biolreprod63.6.1730)

Hall SE \& Saunders PH 1979 Glucose and free fatty acid turn over in normal subjects and in diabetic patients before and after insulin treatment. Diabetologica 16 297-306.

Harvey MB, Arecellana-Panlilio MY, Zhang X, Schultz GA \& Watson AJ 1995 Expression of genes encoding antioxidant enzymes in preimplantation mouse and cow embryos and primary bovine oviduct cultures employed for embryo coculture. Biology of Reproduction 53 532-540. (doi:10.1095/biolreprod53.3.532)

Igosheva N, Abramov AY, Poston L, Eckert JJ, Fleming TP, Duchen MR \& McConnell J 2010 Maternal diet-induced obesity alters mitochondrial activity and redox status in mouse oocytes and zygotes. PLoS ONE 5 10074. (doi:10.1371/journal.pone.0010074)

Iossa S, Mollica MP, Lionetti L, Crescenzo R, Botta M \& Liverini G 2002 Skeletal muscle oxidative capacity in rats fed high-fat diet. International Journal of Obesity and Related Metabolic Disorders 26 65-72. (doi:10. 1038/sj.ijo.0801844)

Jorritsma R, Cesar ML, Hermans JT, Kruitwagen CL, Vos PL \& Kruip TA 2004 Effects of non-esterified fatty acids on bovine granulosa cells and developmental potential of oocytes in vitro. Animal Reproduction Science 81 225-235. (doi:10.1016/j.anireprosci.2003.10.005)

Jungheim ES, Louden ED, Chi MMY, Frolova AI \& Riley JK 2011a Preimplantation exposure of mouse embryos to palmitic acid results in fetal growth restriction followed by catch up growth in the offspring. Biology of Reproduction 85 678-683. (doi:10.1095/biolreprod.111. 092148)

Jungheim ES, Macones GA, Odem RR, Patterson BW, Lanzendorf SE, Ratts VS \& Moley KH $2011 b$ Associations between free fatty acids, cumulus oocyte complex morphology and ovarian function during in vitro fertilization. Fertility and Sterility 95 1970-1974. (doi:10.1016/j. fertnstert.2011.01.154)

Kakinuma K \& Minakami S 1978 Effects of fatty acids on super-oxide radical generation in leukocytes. Biochimica et Biophysica Acta 538 50-59. (doi:10.1016/0304-4165(78)90251-9)

Koskin V, Wang X, Scherers PE, Chan CB \& Wheeler MB 2003 Mitochondrial functional state in clonal pancreatic $\beta$ cells exposed to free fatty acids. Journal of Biological Chemistry 3278 19709-19715. (doi:10.1074/jbc.M209709200)

Kruszynska YT, Worrall DS, Ofrecio J, Frias JP, Macaraeg G \& Olesfsky JM 2002 Fatty acid-induced insulin resistance: decreased muscle PI3K activation but unchanged Akt phosphorylation. Journal of Clinical Endocrinology and Metabolism 87 226-234. (doi:10.1210/jc.87.1.226)

Lane M \& Gardner D 2000 Lactate regulates pyruvate uptake and metabolism in the preimplantation mouse embryo. Biology of Reproduction 62 16-22. (doi:10.1095/biolreprod62.1.16)

Leroy JL, Vanholder T, Delanghe JR, Opsomer G, van Soom A, Bols PE, Dewulf J \& de Kruif A 2004 Metabolic changes in follicular fluid of the dominant follicle in high-yielding dairy cows early post partum. Theriogenology 62 1131-1143. (doi:10.1016/j.theriogenology.2003. 12.017)

Leroy JL, Vanholder T, Mateusen B, Christophe A \& Opsomer G 2005 Non-esterified fatty acids in follicular fluid of dairy cows and their effect on developmental capacity of bovine oocytes in vitro. Reproduction 130 485-495. (doi:10.1530/rep.1.00735)

Leroy JLMR, Van Hoeck V, Clemente M, Rizos D, Gutierrez-Adan A, Van Soom A, Uytterhoeven M \& Bols PEJ 2010 The effect of nutritionally induced hyperlipidaemia on in vitro bovine embryo quality. Human Reproduction 25 768-778. (doi:10.1093/humrep/dep420)

Leroy JLMR, Rizos D, Sturmey R, Bossaert P, Gutierrez-Adan A, Van Hoeck V, Valckx S \& Bols PEJ 2012 Intrafollicular conditions as a major link between maternal metabolism and oocyte quality: a focus on dairy cow fertility. Reproduction, Fertility, and Development 24 1-12 (invited review). (doi:10.1071/RD11901)

Li LO, Klett EL \& Coleman RA 2010 Acyl-CoA synthesis, lipid metabolism and lipotoxity. Biochimica et Biophysica Acta 1801 246-251. (doi:10.1016/j.bbalip.2009.09.024)

Listenberger LL, Ory DS \& Schaffer JE 2001 Palmitate induced apoptosis can occur through a ceramide-independent pathway. Journal of Biological Chemistry 276 14890-14895. (doi:10.1074/jbc.M010286200)
Lonergan P, Rizos D, Gutierrez-Adan A, Fair T \& Boland MP 2003 Oocyte and embryo quality: effect of origin, culture conditions and gene expression patterns. Reproduction in Domestic Animals 38 259-267. (doi:10.1046/j.1439-0531.2003.00437.x)

Lopaschuk GD, Ussher JR, Folmes CDL, Jaswal JS \& Stanley WC 2010 Myocardial fatty acid metabolism in health and disease. Physiological Reviews 90 207-258. (doi:10.1152/physrev.00015.2009)

Lopes AS, Larsen LH, Ramsing N, Løvendahl P, Räty M, Peippo J, Greve T \& Callesen H 2005 Respiration rates of individual bovine in vitro produced embryos measured with a novel, non-invasive and highly sensitive microsensor system. Reproduction 130 669-679. (doi:10.1530/rep.1. 00703)

Lu ZH, Mu YM, Wang BA, Li XL, Lu JM, Pan CY, Yanase T \& Nawata H 2003 Saturated free fatty acids, palmitic acid and stearic acid, induce apoptosis by stimulation of ceramide generation in rat testicular Leydig cell. Biochemical and Biophysical Research Communications 303 1002-1007. (doi:10.1016/S0006-291X(03)00449-2)

Maedler K, Spinas GA, Dyntar D, Moritz W, Kaiser N \& Donath MY 2001 Distinct effects of saturated and monounsaturated fatty acids on $\beta$-cell turnover and function. Diabetes 50 69-76. (doi:10.2337/ diabetes.50.1.69)

McGarry JD 2002 Dysregulation of fatty acid metabolism in the etiology of type 2 diabetes. Diabetes 51 7-18. (doi:10.2337/diabetes.51.1.7)

Metwally M, Citting R, Tipton A, Skull J \& Ledger WL 2007 Effect of increased body mass index on oocyte and embryo quality in IVF patients. Reproductive Biomedicine Online 15 532-538. (doi:10.1016/S14726483(10)60385-9)

Miwa S \& Brand MD 2003 Mitochondrial matrix reactive oxygen species production is very sensitive to mild uncoupling. Biochemical Society Transactions 31 1300-1301. (doi:10.1042/BST0311300)

Mohr LR \& Trounson AO 1981 Structural changes associated with freezing of bovine embryos. Biology of Reproduction 25 1009-1025. (doi:10. 1095/biolreprod25.5.1009)

Mooradian AD, Haas MJ, Wehmeier KR \& Wong NC 2008 Obesity-related changes in high-density lipoprotein metabolism. Obesity 16 1152-1160. (doi:10.1038/oby.2008.202)

Mu YM, Yanase T, Nishi Y, Tanaka A, Saito M, Jin CH, Mukasa C, Okabe T, Nomura M, Goto K et al. 2001 Saturated FFAs, palmitic acid and stearic acid, induce apoptosis in human granulosa cells. Endocrinology 142 3590-3597. (doi:10.1210/en.142.8.3590)

Pasquali R, Pelusi C, Genghini S, Cacciari M \& Gembineri A 2003 Obesity and reproductive disorders in women. Human Reproduction Update $\mathbf{9}$ 359-372. (doi:10.1093/humupd/dmg024)

Reaven GM, Hollenbeck C, Jeng CY, Wu MS \& Chen YD 1988 Measurement of plasma glucose, free fatty acid, lactate, and insulin for 24h in patients with NIDDM. Diabetes 37 1020-1024. (doi:10.2337/ diabetes.37.8.1020)

Rizos D, Ward F, Duffy P, Boland MP \& Lonergan P 2002 Consequences of bovine oocyte maturation, fertilisation or early embryo development in vitro versus in vitro: implications for blastocyst yield and blastocyst quality. Molecular Reproduction and Development $61234-248$. (doi:10.1002/mrd.1153)

Robker RL, Akison LK, Bennet BD, Thrupp PN, Chura LR, Russel DL, Lane M \& Norman RJ 2009 Obese women exhibit differences in ovarian metabolites, hormones, and gene expression compared with moderateweight women. Journal of Clinical Endocrinology and Metabolism 94 1533-1540. (doi:10.1210/jc.2008-2648)

Schmittgen TD \& Livak KJ 2008 Analysing real-time PCR data by the comparative $C(\mathrm{~T})$ method. Nature Protocols 3 1101-1108. (doi:10.1038/ nprot.2008.73)

Shimabukuro M, Ohneda M, Lee Y \& Unger RH 1997 Role of nitric oxide in obesity-induced $\beta$ cell disease. Journal of Clinical Investigation $\mathbf{1 0 0}$ 290-295. (doi:10.1172/JCI119534)

Shimabukuro M, Zhou YT, Levi M \& Unger RH 1998 Fatty acid-induced $\beta$ cell apoptosis: a link between obesity and diabetes. PNAS 95 2498-2502. (doi:10.1073/pnas.95.5.2498)

Sirard MA, Richard F, Blondin P \& Robert C 2006 Contribution of the oocyte to embryo quality. Theriogenology 65 126-136. (doi:10.1016/ j.theriogenology.2005.09.020)

Stojkovic M, Machado SA, Zakhartchenko V, Hutzler P, Gonçalves PB \& Wolf E 2001 Mitochondrial distribution and adenosine triphosphate content of bovine oocytes before and after in vitro maturation: 
correlation with morphologic criteria and developmental capacity after in vitro fertilization and culture. Biology of Reproduction 64 904-909. (doi:10.1095/biolreprod64.3.904)

Stolba P, Kvapil M, Wichterle D \& Dvorak P 1993 Kinetics of free fatty acids in hypertriglyceridemia. Evidence for different types of insulin resistance. Annals of the New York Academy of Sciences 683 373-374. (doi:10. 1111/j.1749-6632.1993.tb35738.x)

Sturmey RG, O'Toole PJ \& Leese HJ 2006 Fluorescence resonance energy transfer analysis of mitochondrial: lipid association in the porcine oocyte. Reproduction 132 829-837. (doi:10.1530/REP-06-0073)

Suarez J, Hu Y, Makino A, Fricovsky E \& Dillmann WH 2008 Alterations in mitochondrial function and cytosolic calcium transients induced by hyperglycemia are restored by over-expression of mitochondrial transcription factor A (TFAM) in cardiomyocytes. American Journal of Physiology. Cell Physiology 295 C1561-C1568. (doi:10.1152/ajpcell. 00076.2008)

Sun QY, Wu GM, Lai L, Park KW, Cabot R, Cheong HT, Day BN, Prather RS \& Schatten H 2001 Translocation of active mitochondria during pig oocyte maturation, fertilization and early embryo development in vitro. Reproduction 122 155-163. (doi:10.1530/rep.0.1220155)

Sutton-McDowall ML, Gilchrist RB \& Thompson JG 2010 The pivotal role of glucose metabolism in determining oocyte developmental competence. Reproduction 139 685-695. (doi:10.1530/REP-09-0345)

Tanghe S, Van Soom A, Nauwynck H, Coryn M \& De Kruif A 2002 Minireview: functions of the cumulus oophorus during oocyte maturation, ovulation and fertilization. Molecular Reproduction and Development 61 414-424. (doi:10.1002/mrd.10102)

Tarin JJ 1995 Aetiology of age associated aneuploidy: a mechanism based on the free-radical theory of aging. Human Reproduction 10 1563-1565. (doi:10.1093/humrep/10.1.165)

Valckx SDM, De Pauw I, De Neubourg D, Inion I, Berth M, Fransen E, Bols PEJ \& Leroy JLMR 2012 BMI-related metabolic composition of the follicular fluid of women undergoing assisted reproductive treatment and the consequences for oocyte and embryo quality. Human Reproduction [in press]. (doi:10.1093/humrep/des350)

Van Blerkom J 2004 Mitochondria in human oogenesis and preimplantation embryogenesis: engines of metabolism, ionic regulation and developmental competence. Reproduction 128 269-280. (doi:10.1530/rep.1. 00240)
Van Blerkom J, Davis P, Mathwig V \& Alexander S 2002 Domains of highpolarized and low-polarized mitochondria may occur in mouse and human oocytes and early embryos. Human Reproduction 17 393-406. (doi:10.1093/humrep/17.2.393)

Van Blerkom J, Cox H \& Davis P 2006 Regulatory roles for mitochondria in the peri-implantation mouse blastocyst: possible origins and developmental significance of different mitochondrial membrane potential. Reproduction 131 961-976. (doi:10.1530/rep.1.00458)

Van Hoeck V, Sturmey RG, Bermejo-Alvarez P, Rizos D, Gutierrez-Adan A, Leese HJ, Bols PEJ \& Leroy JLMR 2011 The effect of elevated NEFA during bovine oocyte maturation on early embryo physiology. PLOS ONE 6 e23183. (doi:10.1371/journal.pone.0023183)

Vanholder T, Leroy JL, Van Soom A, Opsomer G, Maes D, Coryn M \& de Kruif A 2005 Effect of non-esterified fatty acids on bovine granulosa cell steroidogenesis and proliferation in vitro. Animal Reproduction Science 87 33-44. (doi:10.1016/j.anireprosci.2004.09.006)

Wallace DC 1987 Maternal genes: mitochondrial diseases. Birth Defects Original Article Series 23 137-190.

Wilding M, Coppola G, Dale B \& Di Matteo L 2009 Mitochondria and human preimplantation embryo development. Reproduction 137 619-624. (doi:10.1530/REP-08-0444)

Zhang X \& Zhang K 2012 Endoplasmic reticulum stress-associated lipid droplet formation and type II diabetes. Biochemistry Research International [in press]. (doi:10.1155/2012/247275)

Zhang WY, Schwartz E, Wang Y, Atrep J, Li Z \& Reaven P 2006 Elevated concentrations of nonesterified fatty acids increase monocyte expression of $\mathrm{CD} 11 \mathrm{~b}$ and adhesion to endothelial cells. Arteriosclerosis, Thrombosis, and Vascular Biology 26 514-519. (doi:10.1161/01.ATV. 0000200226.53994.09)

Zheng L, Roeder RG \& Luo Y 2003 S phase activation of the histone H2B promoter by OCA-S, a coactivator complex that contains GAPDH as a key component. Cell 114 255-266. (doi:10.1016/S00928674(03)00552-X)

Received 11 May 2012

First decision 21 June 2012

Revised manuscript received 27 August 2012

Accepted 23 October 2012 